\title{
OS ESTILHAÇOS DE MARTINS JÚNIOR E SUA ÉPICA POSITIVISTA: REFLEXÕES HISTÓRICAS SOBRE UMA LINGUAGEM POÉTICA (ANOS 1880)
}

\author{
THE SHARDS OF MARTINS JÚNIOR AND HIS POSITIVIST EPIC: \\ HISTORICAL REFLECTIONS ABOUT A POETIC LANGUAGE (1880s)
}

\author{
Recebido: 12/05/2020 | Aprovado: 09/06/2020 | Publicado: 10/07/2020 \\ DOI: https://doi.org/10.18817/rlj.v4i1.2227
}

Caroline Guebert ${ }^{1}$

Orcid ID: https://orcid.org/0000-0001-6350-7595

\begin{abstract}
Resumo: Este artigo se volta a pensar elementos de uma "epopeia positivista" na linguagem poética de Isidoro Martins Junior (Recife, 1860 - Rio de Janeiro, 1904), a partir dos poemas reunidos no livro Estilhaços, de 1885. Adota-se como chaves de leitura, na construção do objeto, a noção de poesia científico-filosófica e a confluência da retórica na literatura brasileira do período. Inspirando-se na perspectiva de Roger Chartier, busca-se mapear uma agenda de ideias e convenções, cujos usos (pelo poeta) fazem da escrita das práticas um fenômeno relevante para historicizar essa produção. Propõe-se, por fim, um quadro das efemérides cívicas evocadas nos Estilhaços, que triangula as ocasiões públicas de declamação, o mover político e a forma de apreensão de ambos nos (e entre os) poemas.
\end{abstract}

Palavras-chave: História e Literatura. Isidoro Martins Junior. Poesia. Epopeia. Positivismo.

Abstract: This article focuses on elements of a "positivist epic" in the poetic language of Isidoro Martins Junior (Recife, 1860- Rio de Janeiro, 1904), based on poems at the book Estilhaços, from 1885. It's adopted as reading keys in the construction of the object the notion of scientificphilosophical poetry and the confluence of rhetoric in the Brazilian literature of the period. Inspired by the perspective of Roger Chartier, this paper seeks to map an agenda of ideas and conventions, whose uses (by the poet) make the writing of the practices a relevant phenomenon to historicize this production. It's proposed, at end, a board of civic events evoked in Estilhaços, in order to link the public occasions of declamation, the political "move" and the form of apprehension of both in (and between) the poems.

Keywords: History and Literature. Isidoro Martins Junior. Poetry. Epic. Positivism.

\section{Introdução}

O processo de institucionalização da literatura no Brasil permite considerar o século XIX como o momento de sua consolidação: dentre as belasletras, a poesia, cujo edifício tem por andaimes a acomodação das sílabas e a formação do ritmo, era a mais revestida de prestígio (SOUZA, 1999; CHOCIAY, 1979). Antes que um grupo social, cuja atividade exclusiva fosse à produção

\footnotetext{
${ }^{1}$ Graduada em História (UEPG); Mestre em História (UFPR), Doutoranda em História (UFSC NEPEMI: Núcleo de estudos em políticas da escrita, da memória e da imagem), Bolsista CAPES, integrante da equipe do projeto de extensão "Métricas subjetivas do Tempo" (UFSC) e do Podcast "Paratempo". E-mail: carolineap.guebert@gmail.com
} 
literária, havia um estilo de carreira pública centralizada no Estado, incluindo desde empregos no ensino até candidaturas ao parlamento imperial, que "fazia da sobreposição de elites política e intelectual a regra" (ALONSO, 2002, p. 32). A despeito das classificações posteriores que categorizam períodos e autores como mais ou menos romântico, simbolista, parnasiano, realista, etc., por considerar a rica diversidade existente na produção literária da segunda metade do século XIX e início do $X X$, este artigo propõe refletir historicamente sobre as particularidades de uma linguagem literária que marcou aquela conjuntura, clamando ligação com a ciência, especialmente com a filosofia positivista ("a ciência das ciências"). Para contemplar este tema, nosso objeto de estudo é construído a partir da poesia de Isidoro Martins Junior, com foco nos poemas reunidos no livro Estilhaços (1885).

De acordo com Souza (1999), a retórica e a poética situavam-se como saberes disciplinares dos discursos, num compromisso recíproco entre manuais e sistema de ensino, no qual ocupavam lugar de relevo. Amplas funções eram atribuídas à educação retórica: além de "preparar oradores e escritores, apurar as faculdades intelectuais, temperar o caráter e desenvolver o espírito público [...] expandiu os seus efeitos por diversos aspectos da experiência social" (SOUZA, 1999 , p. 112). As elites nutriam grande interesse pelos estudos de retórica (ao qual se anexavam os de poética), cujas convenções atravessaram as formas do discurso e a concepção de literatura, e as transbordavam, espraiando-se no tecido social, a ponto de o relevo cultural da oratória ter sido atribuído como um traço-chave do caráter nacional brasileiro pelos seus pensadores sociais. $\mathrm{Na}$ leitura da produção literária da época há que se considerar essa relação. A atitude filosófica, transformada em elemento poético por Martins Júnior e seus interlocutores, mediava-se pelas finalidades clássicas de ensinar, deleitar, mover².

Para Bosi (2015), a poesia científica que surgiu a partir dos anos 1870, situa-se no quadro mais amplo do realismo, desdobrado num plano ideológico de explicação do real e de uma certeza subjacente dos fatos; e num plano estético de reconhecimento da liberdade no ato de escrever, que conferiam sentido e valor à existência do escritor:

\footnotetext{
2 Era necessária aprovação em exame de retórica para admissão às Faculdades, junto às aulas de vernáculo, latim, grego, poética e filosofia (CARVALHO, 2000). Escritores tinham acesso a modelos discursivos orientadores e a sua produção "retroalimentava a pedagogia das letras à medida que retornava ao circuito escolar, [...] sob a forma de exemplos" (SOUZA, 1999, p. 116).
} 
o ato de negar era fecundo [...] reagindo ao que havia de "caduco na pieguice" dos últimos intimistas, não se tratava apenas de uma retórica de opor-se [...] abriam caminho para o exercício de uma linguagem mais aderente aos sentidos, ao corpo, aos objetos que nos cercam. [...] Sob as influências de Victor Hugo e Baudelaire, diversos poetas brasileiros da segunda metade do século XIX, afirmaram o distanciamento do fulcro subjetivo [...] [como] na frase de Théophile Gautier: "sou um homem para quem o mundo exterior existe" [...] (BOSI, 2015, p. irreg.).

Contudo, é possível ir além e propor particularizações. Conforme Santos (2014), a poesia científico-filosófica foi um movimento representativo dentro da Literatura Brasileira e não é exagero dizer que para os poetas identificados com essa tendência, seus meios, imagens e lógica expressiva se subordinavam ao pensamento de Aguste Comte e nele deviam buscar inspiração. Seu pressuposto implícito era de que os fenômenos humanos, ao invés de individuais, resultam de uma evolução coletiva e contínua e que as artes da escrita resultam do meio em que surgem. Daí a profusão de questionamentos sobre as mutações dos ramos do pensamento e do discurso, e sobre o estado da poesia na sua sociedade.

Nesse repertório, referências a uma crise poética, que tocava nas questões da identidade nacional e da natureza e evolução da humanidade, proliferavam em críticas ao status quo da literatura, marcadas pela angustia de ler o seu tempo como um emaranhado dos estados teológico, metafísico e positivo ${ }^{3}$. A poesia vista como fenômeno social que expressaria o caráter de um povo e uma época, evocava a necessidade de adaptar-se à subjetividade moderna (positiva) para que não desaparecesse. Em livros como A Poesia Científica (1883) e outros da década de 1880, Martins Júnior proclamou que era científica a base da poesia do futuro, com leis positivas por fundamento (BORGES, 2019). Concretizou certa tentativa, portanto, de legitimação da poesia sob a luz positivista. Tratava-se de uma investida, ao mesmo tempo, na sua sociodicéia como intelectual moderno e contra a incoerência que ele e tantos intelectuais do período atribuíam para a "alma brasileira", mediante a sensação de deslocamento

\footnotetext{
${ }^{3}$ Segundo Borges (2019), Martins Júnior via disparidade entre os preceitos metafísicos vigentes e as ideias positivas que surgiam: mesmo com essa separação, retratou a fisionomia da literatura (da poesia em especial) da sua época como difícil de determinar, graças às muitas escolas e campos. Observá-la era como se um "fotógrafo que, tendo de retratar uma criança travessa, visse que ela fazia movimentos e furtava o rosto à objetiva da máquina" (BORGES, 2019, p. 142).
} 
temporal, pautada pela constatação de profundas diferenças e lapsos temporais que separavam a cultura (brasileira) da civilização (ocidental).

A partir dessas questões, visando à possibilidade de tomar o texto literário pelos seus modos históricos, a literatura não é vista aqui como uma espécie "qualquer de representação de totalidades prévias, entendidas como empiria acabada em formulações nas quais 'real' é objetividade ou estrutura econômicopolítica" (CHARTIER, 2000, p. 209). Mas sim discursos que existem como resultados de práticas, interligadas a sistemas de representação. A escrita por vezes faz alusão e tematiza essas práticas, tenta impô-las, quer proibi-las ou governá-las ${ }^{4}$. Roger Chartier (2000) nos inspira a atentar para as condições da produção literária, formadas por codificação retórica, tópicas, regras, meios de circulação, condicionamentos institucionais e públicos, processos e suportes materiais de invenção e transmissão das formas. No caso da poesia brasileira da segunda metade do século XIX, a historicidade passa pela questão da "receita" e da "realização", ou seja, pela tensão entre um sistema expressivo, que existia previamente e a criatividade verbal dos poetas, capaz de diversos matizes: envolve a versificação metrificada, revestida de grande importância, bem como as potencialidades que conferem aos versos andamentos característicos e fazem surgir, em cada estrofe, a cadência silábica, acentual e fônica (CHOCIAY, 1979).

Dialogando com a perspectiva de Chartier (2000), refletir sobre a escrita das práticas numa sociedade, implica assumir os limites advindos da consciência da distância e distinções fundamentais entre práticas escritas (raras em relação à multiplicidade das outras) e não escritas, de modo que a tensão gerada pela irredutibilidade das práticas aos discursos (inclusive nossos, como historiadores) faz parte do objeto de estudo. Como algumas práticas produzem controle, coação e disciplina, mas também táticas de apropriação, invenção, liberdade ou distinção, quando se produz textos? Os textos são encarados como acontecimentos, que têm a potência de romper com legibilidades predeterminadas, baseadas em sistemas de crenças e convenções generalizadas e estabelecer (novas) maneiras de figurar, de produzir e de ler. O poema, particularmente, é um texto arraigado

\footnotetext{
${ }^{4}$ Há uma antinomia nas relações entre as práticas da escrita e as outras: o problema de como os indivíduos e grupos de cada sociedade escreveram práticas e lidaram com essas "transferências" é o que interessa Chartier (2000) ao enfocar a literatura moderna que tematiza a própria literatura.
} 
ao dinamismo criador e verbalizador, para o qual o metro representa a regra abstrata (um dos apoios rítmicos) e uma medida relativamente transferível ${ }^{5}$.

A produção de Martins Junior é indicativa de um trânsito pelo qual passava o próprio conceito de literatura, mediante critérios agenciados pela experiência do cientificismo, do positivismo, do historicismo, etc., que também marcaram a ascensão, por exemplo, da crítica genética, que apostava numa orientação mais historicista, em parte antagônica à retórica clássica dos estudos discursivos. De todo modo, a premissa de que um texto constituía um documento das manifestações da inteligência de um povo/de uma época, no terreno das práticas daquele período, permitia a sua extração retórica. Analiticamente é "prudente admitir-se o caráter cumulativo dessas determinações, sem embargo de serem elas em princípio mutuamente exclusivas" (SOUZA, 1999, p. 113).

A busca por leis e estágios humanos e sociais marcou modos de pensar, fazer, dispor e legitimar a literatura, enquanto categorias do positivismo comteano sofreram apropriações poéticas e usos políticos em meio às polêmicas entre facções das elites: termos foram criados nas controvérsias, expressos em ações e escritos (ALONSO, 2002). Segundo Benoit (2005), a filosofia positivista e suas ramificações foram uma experiência geracional no Brasil ${ }^{6}$ : discípulos de Comte (1798-1857), tanto do Curso de filosofia positiva (1830-1842), quanto do Tratado instituindo a Religião da Humanidade (1851-1858), aderiam à nova ciência, que introduziu, na língua francesa, o neologismo "sociologie", dizendo-se capaz de conter os excessos da subjetividade e de traçar a separação entre a subjetividade antiga e a emergente, aproximando-se de seus preceitos em graus diversos.

A ampla circulação das ideias positivistas no Brasil se fez repleta de tensões, interdependentes aos movimentos republicano e abolicionista. $\mathrm{Na}$ imprensa, o positivismo de alguns escritores chegou a ser retratado e confundido

\footnotetext{
5 "[...] uma receita teórica lhe fixa o número de sílabas e alguns apoios básicos. [...] usualmente chegada ao poeta através do tom normativista dos manuais de versificação, não consegue ser demasiado proibitiva, deixando maior ou menor número de fatores implícitos, cuja exploração e desenvolvimento ficam a cargo do criador e do verbalizador. Para a mais rígida das receitas sempre houve desvios espontâneos ou intencionais de parte dos poetas [...] já que a versificação, como, aliás, qualquer atividade cultural humana, é dinâmica" (CHOCIAY, 1979, p. 35-36).

${ }^{6}$ Além do positivismo comteano, outras teorias circularam e repercutiram, como o evolucionismo de Spencer e o de Darwin, o determinismo de Taine e o de Hackel, etc., mediados por esquemas explicativos do cientificismo da III República francesa e das transgressões literárias da geração portuguesa de 1870. Esse conjunto é analisado por Alonso (2002) a partir de uma abordagem política do movimento intelectual, já que a maneira predominante de expressão era um misto de juízos políticos e intelectuais, ela pensa a relação dos grupos entre si e com esses rótulos.
} 
como um tipo de socialismo e as associações positivistas do eixo Rio-São Paulo assumiriam, de forma crescente, nas últimas décadas do século XIX, um distanciamento com o radicalismo democrático, em nome de um pertencimento elitista e ordeiro. Essas ambiguidades tiveram nuances próprias em cada província e conforme as relações delas com a Corte. São sintomas históricos de transformações sociais e literárias então em curso: como aliar arte e ciência, poesia e modernidade? A arte devia estar acima das doutrinas? Como um projeto filosófico poderia rearticular os modos de operação poéticos? Estas foram questões relevantes na agenda dos literatos daquela conjuntura e particularmente mobilizadas a partir do espaço de Recife, que era um centro de produção cultural, no qual Martins Júnior se encontrava inserido num grupo de "contestadores", que se apresentavam como porta-vozes da política e da literatura científicas. Conforme Braga (2017), não se pode desvincular a sua poesia do território de manifestações pelo fim do Império e de críticas à tríade monarquia, catolicismo e romantismo, tampouco o modo como este poeta e militante agregou a linguagem científica, republicana, ateísta e anticlerical, da busca pela autonomia crítica, tanto política, quanto literária, que partia do norte do Império em relação à Corte.

\section{Vestígios de trajetória e de uma agenda da mocidade em Recife}

José Isidoro Martins Júnior nasceu em Cabo de Santo Agostinho, região metropolitana do Recife em 1860 e faleceu na cidade do Rio de Janeiro em 1904. Segundo Lopes (2019), a origem social da família era financeiramente modesta: foi alfabetizado pelo avô e na adolescência foi trabalhar na capital, onde cursou os estudos secundários. Ingressou na Faculdade de Direito do Recife em 1879, formando-se em 1883. Inseriu-se numa rede de formação e de sociabilidades: realizava trocas e parcerias com Phaleante da Camara, Clodoaldo de Freitas, Generino dos Santos, Tobias Barreto, Clóvis Beviláqua, França Pereira, entre outros. Desde jovem assumiu posição de liderança nos movimentos abolicionista republicano de Pernambuco, presidindo associações: Movimento Ceará Livre; Sociedade Nova Emancipadora; Sociedade Propagadora da Instrução Pública; Clube Republicano; Clube do Cupim, etc. Neles e no seu próprio Clube Martins Júnior (de 1884), permitia e estimulava a participação de mulheres, escravos, ex- 
escravos e operários, além de levantar fundos para alforriar e abrigar escravos fugidos e para a educação científica desses grupos ${ }^{7}$. Segundo Braga (2017), Martins Junior correntemente discursava para grandes plateias, defendendo valores e políticas da liberdade, fraternidade e igualdade: em diversas ocasiões afirmou que todo povo poderia chegar ao mais alto estágio civilizatório, porque a evolução não dependia de fatores biológicos (como muitos contemporâneos afirmavam). Seus discursos causavam alvoroço, como no Congresso Agrícola de 1884, no qual homens reagiram com gritos, agressões de cadeiras e revólveres.

A sua literatura mobilizava categorias tensionadas que estavam em jogo, como: "nouvelle ecole", "intuição nova", "giro das ideias", "idade inovadora", "turbilhão dos sentimentos d'hoje", "batalhões do pensamento" e "reconstrução em roda do presente". O que entendeu por poesia científica mediou tal semântica: para ele "não há somente o concreto nas indagações científicas; há também o abstrato, que é o fato da filosofia, isto é: da verdadeira ciência de conjunto" (MARTINS JR, 1886, p. 13) e a poesia deveria procurar fontes de inspiração na ciência, isto é, na generalização filosófica. Essa ideia coexistia, em seu repertório, com premissas iluministas dos direitos universais do homem e do cidadão.

Uma das profecias políticas de Comte consistia na ideia de "evolução sem revolução" da sociedade, expressa pelo lema do progresso dentro da ordem: ela inspirou alguns positivistas brasileiros a pensarem a república como um Estado (transitório ou definitivo) necessário para realização dessa utopia da sociocracia, que "sintetizava a sonhada meta de estabilização eterna da sociedade burguesa e de exorcismo dos surtos revolucionários da classe trabalhadora" (BENOIT, 2005, p. 53). Contra os princípios da Revolução Francesa de 1789, algumas diretrizes de Comte sustentavam que os humanos nascem e permanecem desiguais em direitos, de modo que a ideia dos direitos universais seria uma metafísica, que ao subverter uma lei da natureza, gerava caos político e desordem. O positivismo supostamente seria então capaz de transformar essa metafísica sonhadora com a orientação das leis científicas. Os usos que Martins Júnior fez do positivismo comteano por certo sinalizam uma leitura independente com relação a tais pontos.

\footnotetext{
7 Havia 25 sociedades abolicionistas existentes em Pernambuco no ano de 1884. E durante o período de luta abolicionista em geral, surgiram ao menos 36 associações femininas no Brasil: destas, de Pernambuco eram a Ave Libertas, a mista Nova Emancipadora e o Clube Martins Júnior, as três com forte ligação com os preceitos republicanos (ALONSO, 2002; BRAGA, 2017).
} 
O livro Estilhaços (1885, Recife, Tipografia Industrial) foi publicado quando o escritor era solteiro e tinha 25 anos, dois anos depois de se formar em Direito. A ocupação profissional de advogado era menos exercida que a de professor: ele lecionava francês, história natural e filosofia no ensino secundário, e em escolas noturnas filantrópicas (gratuitas). Segundo Braga (2017), quando se formou e publicou seus livros, os alunos realizaram procissões até sua casa. Dos gêneros retóricos clássicos, o deliberativo (político), que trata do útil e do honesto e o judicial, que trata do justo e do laudatório (memória e celebração) faziam parte das suas atividades cotidianas. A sua poesia combatente entrou em hiato com a busca por emprego, evidente quando foi reprovado em três concursos públicos, até se tornar professor da Faculdade de Direito do Recife em $1886^{8}$.

Martins Junior reunia ampla produção nos jornais $A$ Luz; O Progresso, Jornal do Recife, O Norte (redator/fundador), etc. Em 1885, já havia publicado cinco livros de poesia: Vigílias Literárias (1879), escritos "poético-científicos" em conjunto com Clóvis Beviláqua; O crime da vitória (1881); Visões de Hoje (1881), livro de bolso, que se tornou um manual da luta política republicana da juventude; A Poesia Científica (1883) e Retalhos (1884). Conforme Borges (2019), as críticas depreciativas aos seus poemas argumentavam contra a compatibilidade da arte com a ciência: Machado de Assis, no texto A nova geração (1879), foi um dos literatos a se opor ao didatismo limitador do movimento de utilização de teorias científicas na literatura. A poesia de Martins Junior, ao mesmo tempo, teve boa recepção de Evaristo de Moraes, Argymiro Galvão, Oliveira Lima e Araripe Junior, cujos elogios enfatizavam menos o "delectare", que o "movere", dentro das finalidades da retórica, segundo a vertente que aliava as artes de pensar a de falar, valorizando a poética como instrumento de argumentação e persuasão. Ademais, a mocidade se atraía pela força da poesia como agente político.

No mesmo ano (1885), Martins Júnior, Clóvis Beviláqua e João Alfredo de Freitas publicaram o texto polêmico Jesus e os evangelhos: uma psicologia mórbida, tradução de Júlio Soury (segunda edição em Recife, pela tipografia Alves de Albuquerque), que retratava Jesus de forma científica, quando essa e

\footnotetext{
${ }^{8}$ Depois ele se tornou Chefe de Polícia de Pernambuco (1889-1890), membro da Comissão da Constituição Republicana (1890), Diretor da Faculdade do Recife (1892-1894), Deputado Federal (1894-1899) e burocrata responsável pela anexação do Acre ao Brasil (1903). A sua produção jurídico-filosófica e de História do Direito, dos anos 1890, teve ampla circulação (BRAGA, 2017).
} 
outras tipografias estavam sendo perseguidas, também devido à impressão de charges ofensivas do Imperador (BRAGA, 2017). Dentro da Faculdade de Direito, o grupo com o qual mantinha afinidade ideológica trocava farpas com o grupo conservador do professor Seabra. Braga (2017) cita que a rivalidade marcou, por exemplo, a eleição para representante (orador) da efeméride pública de 28 de Setembro (aniversário da Lei do Ventre Livre) em Recife, e que após perder, o grupo de Martins Júnior protestou na imprensa e nas ruas anexas à Faculdade. Tais sociabilidades e disputas alimentavam ânimos em torno de Estilhaços.

Em dois poemas de Estilhaços, o eu poético conversa com uma aparição do lexicógrafo francês Emille Littré (1801-1881), cuja interpretação do positivismo Martins Junior endossava, pela "emancipação do espírito, considerando o ateísmo como a única possibilidade que encaminha a um autêntico Positivismo, desprezando a religião da humanidade proposta por Comte" (BORGES, 2019, p. 139), cuja igreja era liderada, na França, pelo filósofo Pierre Laffitte (1823-1903) 9 . Para o poeta brasileiro, a sociologia devia investigavar as leis de desenvolvimento passado e futuro da sociedade e guiar a prática política em direção a objetivos não teológicos e não metafísicos, inspirar a transição da humanidade. Segundo Benoit (2005), a Associação Positivista Brasileira (RJ), em 1876 se definia como composta por epígonos do positivismo incompleto, isto é, sem a religião da humanidade, quanto do positivismo integral, mas em 1881, este se tornou oficial. A importância de se posicionar no território positivista brasileiro, diversamente da diretriz assumida por Miguel Lemos e Teixeira Mendes, fundadores da Primeira Igreja Positivista do Brasil, situada no Rio de Janeiro (a qual se seguiram outras em vários estados), fica evidenciada nos poemas "À Émile Littré" e "A propósito da conversão de Littré". Essa adesão à primeira filosofia de Comte se encontrava nos projetos positivistas para a República e indica as diferenças que existiram entre os positivistas ortodoxos, hetedodoxos, independentes, littreristas, etc.

Outra inflexão relevante é a forma de poesia condoreira que Martins Junior praticou, provida de aspiração idealista de grandeza pela confiança na ciência:

\footnotetext{
${ }^{9}$ Nos anos 1850, Comte transformou os conceitos em dogmas de uma religião que devia substituir o catolicismo e a prática política da filosofia se concentrou na igreja positivista (BENOIT, 2005).
} 
A sua obra é uma espécie de articulação, nos limites da prosa, do lirismo épico e da divulgação do saber. Victor Hugo, Castro Alves, Guerra Junqueiro são, em poesia, os seus modelos. Às rebeldias de Matias Carvalho, acrescenta a deliberação de elaborar um pensamento poético, de realizar em poesia a síntese do saber positivo, que destroçará o lirismo individualista e integrará a poesia nas grandes vibrações do conhecimento (CANDIDO, 2000, p. 259).

Dialogando com Candido (2000), registra-se nos para-textos e mesmo no conteúdo de poemas uma desconfiança de estar saindo dos trilhos poéticos e declarações sobre a inferioridade poética se justificar em função dos valores mais altos que o poeta visaria.

\section{Estilhaços: linguagem poética}

O título de Estilhaços denota um traço de fragmentos poéticos: poemas que estavam espalhados em diferentes suportes, produzidos entre 1877 e 1882, ou seja, escritos a partir dos seus 18 anos de idade. Mas também representa o resultado de uma ação de quebra, um estouro, explicitado em nota preambular:

os naturalistas da arte, que estudem nele a evolução efetuada por meu espírito, a marcha seguida por meu cérebro, durante o período de cinco anos que abrangem os versos aí contidos. [...] Os estilhaços [...] necessitavam, sem dúvida, sair do estado fragmentado a que os forçara a natureza das Vigílias Literárias e formar um todo [...] À Critica resta o direito, que já hoje é um dever, de, mais uma vez, esbordoá-los. Não conseguirá suprimi-los, porém, e isto basta (MARTINS JR, 1885, p. 7).

Uma morfologia inicial dos poemas permite dizer que eles foram criados conforme três modelos de versificação: de sete, de dez e de doze sílabas poéticas, com predomínio dos Dodecassílabos, como se observa no Quadro 1:

\begin{tabular}{|c|c|c|c|c|c|c|c|}
\hline & $\mathbf{1 8 7 7}$ & $\mathbf{1 8 7 8}$ & $\mathbf{1 8 7 9}$ & $\mathbf{1 8 8 0}$ & $\mathbf{1 8 8 1}$ & $\mathbf{1 8 8 2}$ & Total \\
\hline Poemas por ano & 2 & 5 & 14 & 9 & 9 & 17 & 56 \\
\hline Versos Heptassílobos & 1 & 2 & 1 & 1 & & 2 & 7 \\
\hline Versos Decassílabos & 1 & 1 & & & 3 & 6 & 11 \\
\hline Versos Dodecassílabos & & 2 & 13 & 8 & 6 & 9 & 38 \\
\hline
\end{tabular}

Quadro 1 - Poemas do livro Estilhaços por ano e modelo de versos.

Fonte: A autora (2020). 
Conforme o sistema de contagem francesa, que se generalizou para a versificação no Brasil nos tratados oitocentistas, esses dados tomam por base 0 padrão agudo para os finais de verso, isto é, que considera a contagem da(s) sílaba(s) até a última tônica de cada verso metrificado (CHOCIAY, 1979) ${ }^{10}$. Do total de poemas, 11 são sonetos (2 -1879; 2 - 1881; 7 - 1882), modelo que Martins Junior mais destinou para publicações nos jornais na mesma década. Outros 15 variam no número de estrofes (de 2 até 13), mantendo a regularidade de 4 versos por estrofe. O restante é de disposição irregular. Nos processos de versificação, nota-se a preferência pela "abundância verbal, que somente os metros largos lhes poderão convir [...] [e um] excesso palavroso que os conduz, por vezes, ao bestialógico" (CANDIDO, 2000, p. 260). Vinculado a isso, os recursos de acomodação silábica que mais utiliza são os de retração: sinalefa, elisão, crase e sinérese. Isso em parte se explica pelo poeta atentar aos versos alexandrinos, que usam da retração para conectar seus dois hermistícios.

O poema de abertura é um ato de apresentação de um eu poético que lança os versos para a Humanidade como manifesto (“Ide!”). Pela metáfora da revelação da poesia científico-filosófica, a faculdade poética aparece imbricada a do pensamento ("honesta e luminosa"). Ele apresenta a musa da razão, recorre a primeira pessoa e, ao nomear "Introdução aos Estilhaços", usa um termo que remete a prática dos ensaios científicos. Reproduzo aqui um fragmento:

Ide! Agita ao Sol as asas escarlates,

Ó poemas febris! Sois filhos dos combates

Que meu crânio travou no etéreo acampamento

Onde este bom soldado hercúleo - o Pensamento

Tem a sua barraca honesta e luminosa;

E portanto deveis, na face gloriosa,

Mostrar a calma luz dos peitos aguerridos

Que não sabem tremer nem d'arma dos bandidos

Nem da espada leal dos inimigos francos!...

Ide impávidos, pois! Quando os cabelos brancos

Me vierem cercar com um resplendor de lua

A cabeça senil, infecunda, já nua

${ }^{10}$ Os versos atuam como corpo silábico, organizado em função de um corpo maior (a estrofe): acomoda-se o discurso a um esquema pré-estabelecido, que solicita técnica, mas na concretização do poema metrificado atuam também o jogo dos valores vocálicos e consonânticos, a duração de certas sílabas, a entonação, etc. (CHOCIAY, 1979). 
De ideais, de ilusões, de crenças, de esperanças;

Talvez que apenas seja em vós, doudas crianças,

Que eu encontre um regaço, um ninho imaculado,

Onde vá repousar o coração chagado,

- Meu pobre coração ávido só de Bem!...

[...] (MARTINS JR, 1885, p. 11).

No andamento desses versos dodecassílabos, há reiterações de rimas em duplas (lua, nua; esperanças, crianças) e o traço comum da letra $s$ na sonoridade, no início ou fim de palavras. A composição segue a regra da colocação de sílabas tônicas na $6^{\mathrm{a}}$ e na $12^{\mathrm{a}}$ sílabas, usando de sinalefa e elisão como artifícios. $O$ uso dos plurais acentua a construção de uma linguagem para a qual a poesia não decorre apenas de inspiração individual, mas tem no social (lugar dos fenômenos que interessam ao poeta) a condição para a criação, coletivamente orientada. A finalidade retórica e altruística de convencer, persuadir e mover a vontade é evidenciada. Uma vez feitos seus versos, o poeta deseja se reencontrar com eles: devem ser capazes de restabelecer a veia útil e construtora da poesia, ligada ao princípio evolutivo evocado pelo par coração/humanidade. Contra a distorção da realidade e a dispersão dos ideais, a poesia soa como unidade, que encarna a subjetividade nutrida no homem pela força da razão do mundo exterior. Continua:

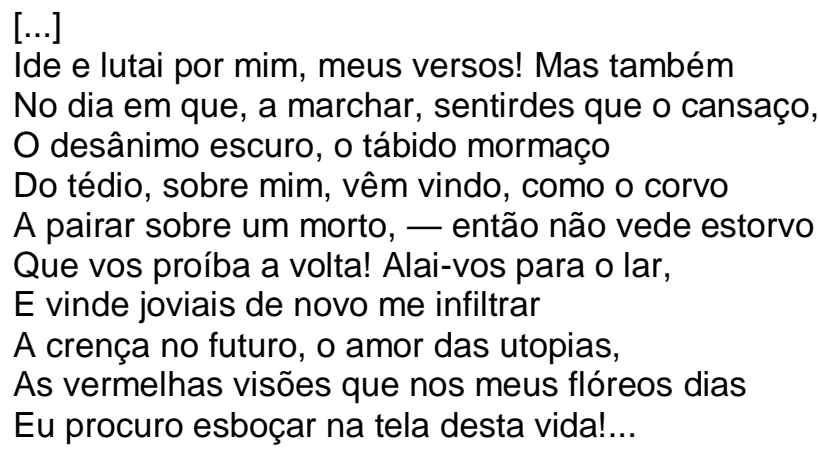

A partir das pausas, um morto, um estorvo e um corvo complementam-se em uma metáfora das práticas não ligadas ao pensamento nas relações entre individuo e sociedade. Os versos recém-nascidos são o ninho do renascimento. A última estrofe de um verso só resume o poema inteiro e se destaca pela sua 
duração diferenciada dos versos anteriores, que seguem um mesmo esquema de sílabas. Conclui que a poesia lança luz sobre o pensamento e se torna abrigo, capaz de orientar o futuro: as visões que a criam, diante dos adversários e dos combates do próprio eu poético, são uma espécie de movimento contra "a anarquia nos crânios e nos peitos" (o caos coletivo). Em outros poemas esse caos é a imagem abstrata da musa romântica, do sentimentalismo ou erotismo oco que atribui a um romantismo "sombrio", "morto" unificado, sobre o qual odeia "a falta de ideias e a abstenção política. E como os desanca!" (CANDIDO, 2000, p. 259). O caos também é personificado pelos estados de espírito metafísico e religioso, não raras vezes observado pelo eu poético em coexistência com o espírito positivo, nas mais diversas ocasiões sociais. A Introdução se fecha com uma citação de Berthezène (O Progresso), demarcando que escreve para pensadores.

Mantém-se nesse livro o paralelo entre a política e a arte, explicitado no Visões de Hoje: segundo Borges (2019), amarradas pela concepção filosófica de Comte, a arte, auxiliar da razão e da verdade, teria por função a sensibilização moral, a educação do homem e o aperfeiçoamento da sociedade por meio do belo. Trata-se de uma concepção humanista, na qual a arte é social e política, além da fruição. O poeta exprime a preocupação de interiorizar ciência pela arte e a "criação poética é um capítulo dentro da luta pela evolução da sociedade e dos indivíduos, o que vale dizer que estamos diante de elementos iluministas que ainda vigoravam [...] de que o Positivismo é herdeiro" (SANTOS, 2014, p. 3).

Nos Estilhaços o gênero predominante é a epopeia: poema em estilo oratório, que exalta as ações memoráveis de um herói histórico (ou lendário), que representa uma coletividade. Há lugar para o elogio fúnebre, em memória de alguém e para contar história utilizando-se da poesia. Em vários poemas um eu poético observa os fenômenos, posicionando-se como testemunho, além de se inspirar nos feitos dos heróis. Por vezes o poeta conversa com esses heróis, com a musa da História (Clio) ou com o "espírito do povo", dirigindo a eles homenagens às conquistas patrióticas do passado, que contribuíram para o progresso da humanidade, especialmente para a superação do estado em que predominam "as lendas, o mistério, as velhas teogonias / fabricadas da cor das noites mais sombrias" (MARTINS JUNIOR, 1885). Atente-se a um fragmento do 
poema "Salve", que alude ao primeiro aniversário do Decreto de 19 de abril de 1879, que reformou o ensino superior no Império e instituiu o ensino livre:

\author{
$[\ldots]$ \\ Quando nos crânios possantes \\ Dos corpos livres e novos \\ Vibra a célula da luta, \\ Que abala os mundos e os povos; \\ Irrompe a douda voragem \\ Treda, sublime, selvagem, \\ Que lança a Terra no pasmo, \\ E a Mocidade e o Direito \\ Abrindo a cratera - peito \\ Mandam falar o entusiasmo! \\ É este o espetáculo enorme \\ Que vós nos dais neste instante: \\ - A Luz saudando a Ciência, \\ - A mocidade triunfante! \\ Aqui, neste templo augusto, \\ Em que das Artes o busto \\ Radia como um farol, \\ Eu sinto que as vossas almas \\ Passam, no meio das palmas, \\ Deixando résteas de sol! \\ [...] (MARTINS JR, 1885, p. 141-142)
}

Este poema foi escrito quando Martins Júnior estudava na Faculdade de Direito, cujos estudantes constituíram o público para o qual foi recitado numa festa solene. O eu poético fala sobre a mocidade e para ela, situando que suas ideias valem epopeias e monumentos no seio da história. Poema longo, com 8 estrofes de versos heptassílabos (sendo a primeira e a última repetidas), elas produzem um movimento de reafirmação, que dota o poema de continuidade, sem grandes contrastes temáticos, acentuais ou fônicos. O Direito (as leis) e a Mocidade formam uma musa dupla. Reelabora como espetáculo a reunião dos jovens e como templo a instituição de ensino, que tem a verdade (a vida da ideia) e a liberdade (na lei) como palavras de ordem, que passavam a mudar as práticas, e que serviram de mote da própria reunião reelaborada pelo poema. Há, novamente, o ângulo pessoal ("eu sei”), com a presença incessante do poeta nas imagens retumbantes. Apesar de não considerar que a linguagem se reduz a uma extensão do romantismo condoreiro, concordamos com Candido (2000, p. 260) que ela lhe é tributária, e que escancara uma "tentativa de bater ainda mais 
largamente as asas da oratória humanitária ou revolucionária, vibradas pelos poetas românticos da terceira fase", que se estende a uma busca deliberada de um estado de transe oratório, numa visão exaltada do progresso: "Era a música divina / Da liberdade do estudo / Era o ensino passado / Que tombava estéril, mudo. O oficialismo caía / Entre a caligem sombria / Que Ihe toldava o viver" (MARTINS JR, 1885, p. 143-144).

Como uma espécie de meta-linguagem nos poemas, as efemérides nacionais, a erudição histórica e a retórica jurídica criam o heroísmo da razão. $A$ linguagem poética de Martins Junior lança como musa uma síntese das paixões da Humanidade (amor, justiça e verdade), que "se alinha à máxima positivista: o amor por princípio, à ordem por base e o progresso por fim" (BORGES, 2019, p. 150). Observe o fragmento do poema decassílabo "Lição de História”, a seguir:

\author{
$[\ldots]$ \\ A Forca tinha sido levantada \\ Bem no meio da praça. A luz, vibrada \\ Pelo nervoso sol americano, \\ Vinha bater no tronco desumano \\ Daquele poste afoitamente erguido \\ Para o côncavo céu louro e brunido. \\ A alma grande, feita de ouro e de aço, \\ Que o Povo tem para os solenes dias, \\ Pulsava ali em curvas fugidias \\ Como no mar um ramo de sargaço; \\ E enquanto a plebe, entre os soldados bruscos, \\ Via luzir os duros sabres fuscos \\ Pousados nus em musculosos ombros, \\ [...] (MARTINS JR, 1885, p. 137)
}

Neste poema, alguns termos constituem inversões semânticas possibilitadas pela poesia. Dialogando com Carvalho (2000), a palavra plebe como o conjunto dos cidadãos livres, aproxima-se da definição dos dicionários políticos publicados pelo movimento republicano no período: é o povo com sua "alma grande, feita de ouro e de aço". Distingue-se do conceito tradicional de plebe como gente de vícios, baixezas e maus costumes: quem constitui esse polo na poesia, representado pela imagem do vampiro, lascivo e de "alma negra" é o rei, um assassino, que ri nos braços da sua amante (a marquesa), enquanto o herói é enforcado. O ataque dos tiranos contra o pacto social e a conspiração dos 
cidadãos virtuosos (multidão que sofre) em defesa desse pacto, remetem a disputas doutrinárias por significados. Nesse sentido, são construções tanto poéticas, como políticas, que fazem usos de termos destinados a construção de novos símbolos, monumentos e mártires: "Pôs-se a embalar o mártir, cujo esquife/ Era a amplidão.... Findara RADCLIFF!" (MARTINS JR, 1885, p. 138). O herói do poema valoriza a mudança: João Guilherme Ratcliff foi enfocado como líder da Confederação do Equador (1824), uma das duas grandes revoluções pernambucanas (a Revolução de 1817 é, também, mencionada em poemas), originadas de movimentos separatistas e republicanos do passado e que ajudaram a criar um ethos da mentalidade moderna dos pernambucanos perante a Corte Imperial. Se em algumas estrofes opera uma sacralização poética de fatos e espaços cívicos, em outras usa da ironia, do deboche e do argumento ad personam para desqualificar os opositores, atacando sua moral, traço comum do estilo de debate político estabelecido na imprensa da época. O eu poético observa duas situações (dois polos) que envolvem valores: 1) o enforcamento em praça pública do líder da república criada em Pernambuco em 1824, cujo nome que é grifado em letras maiúsculas, como se verbalizasse um grito, quando de sua morte; 2) o polo do poder imperial que castiga. O poeta opera traços de contrastes e pausas entre essas imagens:

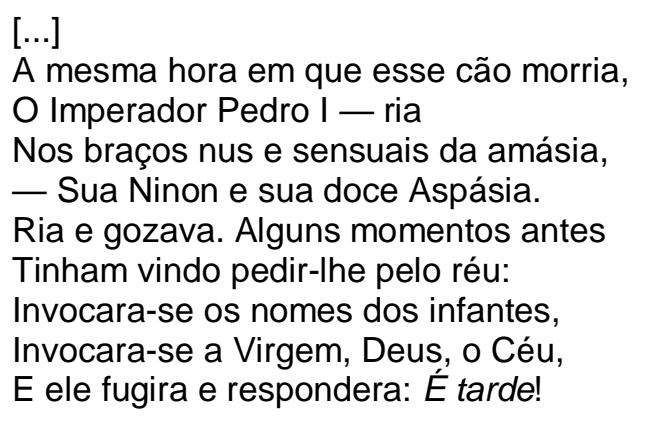

[...] (MARTINS JR, 1885, p. 139).

A última estrofe é inteira formada por palavras perversas que saem da boca de Dom Pedro I quando ele vê o cadáver do herói, marcadas pelo recurso das aspas: "[...] Su'alma negra apenas teve um brado: / — "Marquesa, corre em meu real encalço! / "Quero um milhão de beijos e de abraços! / "Olha: Eu desejo 
te pender dos braços / Como aquele vilão do cadafalso!" (MARTINS JR, 1885, p. 139). O ataque e o elogio pessoal, olhado pelo prisma da retórica, faz com que a autoridade de uma pessoa e de um argumento se amarrem: essas noções tinham por princípio evidenciar a virtude do personagem, pela relação entre uma obra (para a humanidade, no sentido comteano) e a pessoa que a realiza, também mobilizada, em outros poemas, com relação aos românticos, acusados de boêmios e aos senhores de escravos. Segundo Carvalho (2010), aderir a este estilo era uma maneira de garantir certa eficácia retórica e política, quando o próprio público puxava na direção do argumento pessoal. O recurso corroborava no esforço de criação de uma nova linguagem poética, atrelada ao projeto republicano de constitucionalismo, governo liberal e contrato social, e a tarefa altruísta de inculcar tal linguagem nos cidadãos dos novos tempos. Em vários poemas há, também, semelhança com o gênero laudatório, ou epidíctico, da retórica, caracterizado como um espetáculo de exibição de talentos oratórios, que estabelece uma relação poética que se destina a questionar valores da sociedade, na qual que pesa uma adesão do leitor/ouvinte ${ }^{11}$.

Espaços destinados para aplausos e contemplação, na forma escrita desses poemas, ganham traços pontilhados de uma até quatro linhas, conforme o tamanho da pausa esperada: este elemento é muito usado nos Estilhaços e é indicador da materialidade das condições de produção dos poemas, sobretudo porque eram feitos para serem lidos em voz alta e, não raro, em eventos públicos, vários, portanto, com temáticas pré-definidas em torno de datas e figuras cívicas. Traço que autor e/ou editor optavam para o impresso e que tentava direcionar a leitura. Os pontilhados e onde são inseridos imprimem características aos poemas, assim como as pausas sensíveis internas ou finais previstas em versos, essas pausas de estrofes alteram "as balizas anteriores e posteriores ao silêncio permitido por elas" (CHOCIAY, 1979, p. 3). Não à toa no "Lição de História", já mencionado, a estrofe dentro das duas pausas pontilhadas, guarda o conteúdo controverso de uma imagem da vida erótica do imperador brasileiro, promovendo inversões poético-históricas na epopeia da nação, convencido do impacto da forma entre ouvintes e leitores. Vale lembrar que os tratados de retórica

\footnotetext{
${ }^{11}$ A agressão (desmoralização) pessoal era um estilo de argumentação, diferente do agumentum ad hominem, mas que, em debates políticos, muitas vezes se misturavam (CARVALHO, 2010).
} 
recomendavam que a audiência deveria determinar o estilo do orador e dos argumentos: assim, as cinco operações retóricas (invenção, disposição, memória, elocução, pronunciação) dos poemas variam ao longo dos anos e ocasiões. Permanece o discurso binário de monarquia/egoísmo e república/altruísmo, transformando a memória dos eventos anti-monarquistas da história em inspirações de uma linguagem poética que panteoniza, como as poliantéias:

Por seguirem o calendário positivista, as poliantéias - números de jornais únicos dedicados à memória de um ilustre - tornaram-se comuns a partir da década de 1880 [...] importantes no panteão histórico. Camões e o Marquês de Pombal, vistos por eles como indivíduos que contribuíram para o engrandecimento da nação, foram homenageados em 1880 e 1882, respectivamente. Na visão deles, grandes estadistas são aqueles que regem de maneira ilustrada (BRAGA, 2017, p. 91).

Com expressões tributárias ao Canon de expressões e valores estéticos do mundo greco-romano (vesúvios, gigantes, ninons, etc), saudava-se a complementaridade entre antigos e modernos, evocando 0 signo do Renascimento, que ganhava relevo com a construção comparações dos heróis modernos com o belo daquela civilização, contrastados com a temática das "trevas" e do "atraso". Ilustração e Revolução são matrizes de pensamento que sobrevivem ao romantismo e, como herança das luzes, continuariam a se expandir e a iluminar caminhos dos povos, neste caso o brasileiro. Segundo Borges (2019), para Comte, a tradição, centrada no classicismo grego, teria a capacidade de converter as paixões individuais em força coletiva. A idealização de figuras exemplares na linguagem poética de Martins Junior se pauta na crença da capacidade dessa tradição ser estímulo para a Nação e para a Humanidade.

A partir das questões mencionadas, realizei um mapeamento dos elementos de épica histórica e celebração patriótica que permitem traçar relações intra e inter poéticas nos Estilhaços. Essa apreensão literária da realidade (ou escrita das práticas), encontra-se sistematizada no Quadro 2:

\begin{tabular}{|c|c|c|c|}
\hline Poema(s) & $\begin{array}{c}\text { Datas cívicas na } \\
\text { linguagem poética }\end{array}$ & Ocasião & $\begin{array}{c}\text { Pessoas e/ou lugares } \\
\text { mencionados }\end{array}$ \\
\hline $\begin{array}{c}\text { A Antônio } \\
\text { Pedro; }\end{array}$ & $\begin{array}{c}30 \text { anos do Gabinete } \\
\text { Português de Leitura }\end{array}$ & $\begin{array}{c}\text { Sessão magna, noite de } \\
\text { benefício ao Gabinete }\end{array}$ & $\begin{array}{c}\text { Antônio Pedro de } \\
\text { Figueiredo (1814-1859), }\end{array}$ \\
\hline
\end{tabular}




\begin{tabular}{|c|c|c|c|}
\hline Ciência e Arte & (criado em 1851) & Português (PE, set. 1881) & escritor, professor Recife. \\
\hline $\begin{array}{l}\text { Fiat lux!; } \\
\text { A França }\end{array}$ & $\begin{array}{c}\text { 1789: } \\
\text { Revolução Francesa. }\end{array}$ & & $\begin{array}{l}\text { Brasil; Gália, Girondinos, } \\
\text { Victor-Hugo, Comte }\end{array}$ \\
\hline AWAY & $\begin{array}{c}11 \text { ago. 1827: criação } \\
\text { Faculdades de Direito } \\
\text { no Brasil. }\end{array}$ & $\begin{array}{l}\text { Por ocasião de } \\
\text { comemorar-se o dia "dia da } \\
\text { pendura" em } 1878 .\end{array}$ & Brasil \\
\hline $\begin{array}{l}\text { A Memória de } \\
\text { Tiradentes; } \\
\text { Ao Povo; } \\
\text { Tiradentes. }\end{array}$ & $\begin{array}{l}21 \text { de abril de 1792: } \\
\text { Execução pública de } \\
\text { Tiradentes. }\end{array}$ & $\begin{array}{l}\text { Comemorando o dia } 21 \text { de } \\
\text { abril (1882). }\end{array}$ & $\begin{array}{c}\text { Tiradentes (1746-1792) e } \\
\text { Tomás A. Gonzaga (1744- } \\
\text { 1810), líderes da Revol. } \\
\text { Mineira de } 1789 .\end{array}$ \\
\hline Salve! & $\begin{array}{l}19 \text { abr. 1879: Reforma } \\
\text { do ensino superior }\end{array}$ & $\begin{array}{l}\text { Espetáculo do aniversário } \\
\text { do Decreto de } 19 \text { de abril }\end{array}$ & \\
\hline $\begin{array}{l}\text { A Pombal; } \\
\text { O Marquês. }\end{array}$ & $\begin{array}{l}\text { Centenário de Pombal } \\
\text { (1882) }\end{array}$ & $\begin{array}{l}\text { Festa "Pernambuco ao } \\
\text { Marques de Pombal" }\end{array}$ & $\begin{array}{c}\text { Marques de Pombal (1699- } \\
\text { 1782): estadista ilustrado }\end{array}$ \\
\hline $\begin{array}{l}\text { Lição de } \\
\text { Historia }\end{array}$ & $\begin{array}{l}\text { Confederação do } \\
\text { Equador (PE, 1824) }\end{array}$ & & $\begin{array}{l}\text { João Ratcliff (1776 - 1825), } \\
\text { líder Confed. do Equador }\end{array}$ \\
\hline Duas Épocas & $\begin{array}{l}\text { Tricentenário de } \\
\text { Camões }\end{array}$ & & $\begin{array}{c}\text { Luiz Vaz de Camões } \\
(1524-1580), \text { poeta } \\
\text { português - Os Lusíadas }\end{array}$ \\
\hline $\begin{array}{l}6 \text { de Março; } \\
\text { Os Avós; } \\
\text { Ao Povo }\end{array}$ & $\begin{array}{c}06 \text { mar.: } \\
\text { Revolução } \\
\text { Pernambucana de } 1817\end{array}$ & & $\begin{array}{l}\text { Domingos Teotônio Jorge, } \\
\text { líder da Revolução de } 1817\end{array}$ \\
\hline $\begin{array}{c}\text { Mavortia } \\
\text { Civitas }\end{array}$ & $\begin{array}{l}\text { Invasão Holandesa em } \\
\text { Pernambuco Colonial }\end{array}$ & & Olinda \\
\hline $\begin{array}{l}\text { À Propósito } \\
\text { da Conversão } \\
\text { de Littré }\end{array}$ & & & $\begin{array}{l}\text { Emile Littré (1801-1881), } \\
\text { lexicógrafo francês, autor } \\
\text { do Dicionário Litrré }\end{array}$ \\
\hline Tenebrae & $\begin{array}{l}\text { Hecatombe de Vitória: } \\
\text { conflito entre Liberais e } \\
\text { Conservadores, } 27 \text { jun. } \\
\text { 1880: assassinatos. }\end{array}$ & $\begin{array}{c}\text { Por ocasião dos } \\
\text { acontecimentos em Santo } \\
\text { Antão: centenas de } \\
\text { pessoas mortas (1880). }\end{array}$ & $\begin{array}{l}\text { Vitória de Santo Antão (PE) } \\
\text { - cidade a } 53 \text { km de Recife; } \\
\text { Igreja de Nossa S. do } \\
\text { Rosário dos Pretos. }\end{array}$ \\
\hline $\begin{array}{l}\text { Hino Ideal; } \\
\text { Avé! }\end{array}$ & $\begin{array}{c}\text { Conquistas } \\
\text { Abolicionistas, } \\
\text { libertações de filhos de } \\
\text { escravizados pela Lei }\end{array}$ & $\begin{array}{c}\text { Festival do Clube } \\
\text { Abolicionista, } 28 \text { set.1882, } \\
\text { Theatro Santa Isabel; } \\
\text { Em Festa da Assoc. Abolic. }\end{array}$ & \\
\hline $\begin{array}{l}\text { No Túmulo do } \\
\text { Dr. Aprígio } \\
\text { Guimarães; } \\
\text { A Memória de } \\
\text { Joviano M. }\end{array}$ & In Memorium & $\begin{array}{l}\text { Falecimentos e Cerimônias } \\
\text { fúnebres diversas (1878 - } \\
\text { 1882); Dia de Finados. }\end{array}$ & \\
\hline $\begin{array}{l}\text { A Carlos } \\
\text { Gomes }\end{array}$ & $\begin{array}{l}\text { Visita de Carlos Gomes } \\
\text { ao Recife em } 1879\end{array}$ & $\begin{array}{l}\text { Espetáculo de homenagem } \\
\text { ao amigo }\end{array}$ & $\begin{array}{l}\text { Antonio C. Gomes (1836- } \\
1896) \text {, compositor óperas. }\end{array}$ \\
\hline
\end{tabular}

Quadro 2: Mapeamento de efemérides cívicas nos Estilhaços (1885).

Fonte: A autora (2020).

Entre o "dia da pendura", comemorações abolicionistas, cerimônias fúnebres e filantrópicas, a presença cênica do orador foi poetizada por Martins Júnior, cheia menções históricas: o poeta, com sua presença real ou simbólica em eventos que vão da Invasão Holandesa à Revolução Pernambucana, passando pela França revolucionária, os poemas criam uma epopeia da transformação. Estilhaços das ideias antigas se constroem via saudações rítmicas aos fervorosos ideais e suas radiações, ao esplendor lutas e "vidas-clarões", em atitudes de 
saudação: altar, memória, imortal, albor, dever, preito, ancião e ancestral são termos típicos.

No repertório explorado aqui, concordando com Braga (2017), seus versos se transformam numa conversa sobre o devir da nova geração. Os indicadores das datas históricas na construção dessa linguagem literária indicam traduções poéticas a absorver práticas científico-filosóficas pela escrita, que soavam como tarefa urgente. O poeta, ao longo das composições do livro, lança repetidamente pares de oposições entre a nova era e as velhas compreensões, e costuma terminar os poemas com imagens de uma festa gerada pelo giro (pela inversão) das ideias no "século dezenove - o herege luminoso" (MARTINS JUNIOR, 1885).

Nos Estilhaços, menos preocupado que em livros anteriores em vislumbrar uma fórmula poética que sintetizasse as ideias positivistas, permanece o ideal de uma poesia que urgia em ser contemporânea: a insistência pela transformação e pla marcha do progresso, elege a ciência o direito e a história como guias, empregando um filosofismo didático e panfletário. O tom pedagógico do texto ganha enunciação ritual, coletiva, que faz da elocução de orientação científico-filosófica uma condição da literatura do seu tempo, e que reatualiza (ou tenta reatualizar) a autoridade de um gênero como a epopeia. Os poemas integram este gênero temporalmente amplo na poesia e convida-nos a pensar suas variações. Conforme a relação levantada por Chartier: "Quando um historiador se ocupa da literatura, a literatura é especificamente documento do quê?", pode-se dizer que entre as vozes ocupadas com a arte da poesia nos anos 1880, os temas trabalhados neste artigo a partir de Estilhaços nos permitem supor que se trata de um livro situado numa encruzilhada da sobrevivência e reinvenção da poesia (épica), numa configuração social profundamente mexida pelo desenvolvimento e difusão das ciências e pela eloquência, repertórios ao qual Martins Júnior não deixou de recorrer para estilhaçar certos pilares da tradição intelectual imperial.

\section{Referências}

ALONSO, Angela. Ideias em movimento: a geração 1870 na crise do Brasil Império. São Paulo: Paz e Terra, 2002. 
BASTOS, Filinto J. Discurso no festival do Club Abolicionista em noite de 28 de setembro de 1882. Typographia Mercantil, Recife, 1883.

BENOIT, Lelite Oliveira. Progresso dentro da ordem: a filosofia positivista no Brasil. História Viva, n. 9, Brasil/Portugal, 2005, p. 46-53.

BOSI, Alfredo. História concisa da literatura brasileira. São Paulo: Cultrix, 2015.

BRAGA, Flavia. Ditadura, Abolição e República: a propaganda da geração positivista em Pernambuco. Dissertação (Mestrado História). UFPE, Recife, 2017.

BORGES, Isabela Melim. As influências do positivismo na poesia de Sílvio Romero e de Isidoro Martins Júnior. In: BORGES; PERGHER (orgs). A literatura e seus híbridos. Florianópolis: UFSC, 2019.

CANDIDO, Antonio. A morte da águia. In: Formação da Literatura Brasileira (momentos decisivos). Primeiro Volume. Belo Horizonte: Editora Itatiara, 2000.

CARVALHO, José Murilo de. História intelectual no Brasil: a retórica como chave de leitura. Topoi, Rio de Janeiro, nำ 1, pp. 123-152, 2000.

CHARTIER, Roger. Debate Literatura e História. Topoi, Rio de Janeiro, n. 1, pp. 197-216, 2000.

CHOCIAY, Rogério. Teoria do Verso. São Paulo, McGraw-Hill do Brasil, 1974.

LOPES, Raimundo Helio. Martins Junior. Verbete CPDOC. Acesso em: 12 out. 2019. Disponível em <http://cpdoc.fgv.br/sites/default/files/verbetes/primeirarepublica/MARTINS\%20J\%C3\%9ANIOR,\%20Jos\%C3\%A9\%20Isidoro.pdf>

MARTINS JUNIOR, José Isidoro. Estilhaços. Recife: Tipografia Industrial, 1885.

SANTOS, Alckmar dos. Ciência e poesia. Mafuá, Florianópolis, n. 21, p. 2014.

SOUZA, Roberto Acízelo de. O Império da Eloquência: retórica e poética no Brasil oitocentista. Rio de Janeiro: EdUERJ/EdUFF, 1999. 